REVOLUTION AND EVOLUTION IN ECONOMIC THEORY

by

Jurg Niehans

DISCUSSION PAPER 92.20

OCTOBER 1992 




\title{
REVOLUTION AND EVOLUTION IN ECONOMIC THEORY
}

\author{
by \\ Jurg Niehans* \\ Professor Emeritus \\ University of Switzerland \\ Adjunct Professor \\ University of California Santa Cruz
}

DISCUSSION PAPER 92.20

OCTOBER 1992

\begin{abstract}
THE BATEMAN MEMORIAL LECTURE
delivered at The University of Western Australia

on October 12, 1992
\end{abstract}

ISSN 0811-6067

ISBN 0-86422-220-3

* The author's address is: 290 Paseo Bernal, Moraga, CA 94556 
I. Introduction 1

There is a widespread impression today that the history of economics is a sequence of revolutions and counterrevolutions, successive schools rising to dominance just to be deposed in a crisis by another school. According to this view, paraphrasing Marx, all history of economics is a history of school struggles, punctuated by revolutions. $^{2}$

In part, of course, this is merely a question of jargon, of academic marketing, of rhetorics. Each of us is free to use his (or her) words as he pleases; there is no accounting for taste, as a Latin proverb says. If one likes to call a better mousetrap a revolution, who wants to dispute him? In part, however, the revolutionary interpretation of doctrinal history is a substantive question of considerable importance, because it creates the discouraging impression that the history of our science consists mostly of unending controversy with little cumulative progress. It is this substantive question which is the subject of my lecture.

I do not want to discuss this question for economic science as a whole. Modern economics is a many-splendored thing. In part it consists in the understanding of history, particularly economic history. In part it consists of policy prescriptions, "doctrines", most of them ever-changing and controversial. Another part of economics is undoubtedly science, namely economic theory. And finally, to a very important extent, economics is an art, the art of building theoretical models that lead to useful policy prescriptions under particular historical circumstances. ${ }^{3}$ The present discussion shall be limited to just one part of the whole, namely economic theory.

1 This paper elaborates a view of the dynamics of progress in economic theory which was briefly outlined by the author at the end of Niehans (1990).

2 Hutchison (1978) provides an abundance of pertinent references and observations on many aspects of "revolutions" in economics.

3 This interpretation of economics is elaborated in Niehans (1981). 


\section{Models of Revolutionary History}

For such a discussion we first have to clarify what we mean by "revolutions" in economics. Sometimes this word is used simply to identify certain phases of relatively rapid change. ${ }^{4}$ This is an uninteresting terminology, because it is obvious that in this sense scientific progress, like everything else, even a sequence of random numbers, has its "revolutions". The more interesting question is whether there is in the progress of economic theory an inherent dynamic mechanism in which revolutions play an essential role. Let me illustrate by a mechanical analogy. A water wheel transforms the continuous pressure of the water into the continuous rotating motion of the wheel. This is clearly a metaphor for a non-revolutionary process. In a steam hammer, however, the continuous pressure of the steam is transformed into the reciprocating motion of the hammer. This would be a metaphor for a revolutionary process. Its essential elements are the gradual building-up of the steam pressure, the sudden relaxation of this pressure once it has reached a critical point, and the periodic drop of the hammer. Do we find such a relaxation mechanism in the history of science?

\section{Kuhn's Paradigm Change}

It is now exactly 30 years since Thomas Kuhn argued that we do (Kuhn 1970). In his model, empirical observations accumulate relentlessly, perhaps randomly. The scientific theories, which are the handiwork of "normal science", should always, in principle, reflect the contemporaneous state of empirical knowledge. As a matter of fact they don't. The reason is that, besides on observation, theories are also based on a certain dominant view on how the world is built. This "world view" is what Kuhn called, misleadingly, a "paradigm". This paradigm, precisely because it is more a preconceived notion, a metaphor, than a scientific theory, is rigid, incapable of continuous adjustment. Since the scientific theories are, so to say, glued to this rigid

4 In this sense Samuelson spoke of a "monopolistic competition revolution" (Kuenne 1967, 105, 138). 
paradigm, they cannot continuously adjust to the accumulating observations. As a consequence, there is a growing tension between theory and observation. Once the tension exceeds a certain point there is a crisis, normal science is at an impasse, the paradigm has to be abandoned and replaced by a new one. This is a scientific revolution. The history of science, therefore, is a history of scientific revolutions.

\section{Schumpeterian Historiography}

Several years before Kuhn, Joseph Schumpeter thought he had detected a similar cyclical mechanism in the history of economics. He died before he had completed the section in which he had planned to elaborate this idea, but his posthumous History of Economic Analysis is clear about its essential elements. After the first synthesis of Adam Smith, a classical cycle was supposed to have begun with fresh activity that struggled hopefully with the deadwood, followed by the next classical synthesis of John Stuart Mill and finally by stagnation (Schumpeter 1954, 380). The marginalist cycle then began around 1870 with revolutions and two decades of struggle, followed by another "classical situation" eventually showing signs of decay (754). With this model, Schumpeter had essentially transferred his own theory of business cycles, with its periodic innovational breakthroughs, from the economy itself to economic science. Growth seems to consist of cycles of "creative destruction", both in the economy and in theory.

\section{Marxian (Hegelian) Dialectics}

In reading Kuhn's or Schumpeter's descriptions of scientific progress, it is almost impossible for an economist to overlook the close analogy to the Marxian model of history. ${ }^{5}$ Schumpeter, though not a Marxist, was very much aware of his intellectual

5 Among those who did not overlook it is Martin Bronfenbrenner, as one would expect. In his own words: "Kuhn's own catastrophic theory sounds sometimes like a sophisticated grandson or grandnephew of the Hegelian or Marxian dialectic" 
debt to Marx. Kuhn does not mention Marx, but Marxian ideas have spread far and wide, also among non-Marxists, so that an indirect influence cannot be excluded. For Marx it is the "productive forces", particularly technology and natural resources, that move relentlessly forward. To each state of the productive forces there belongs a corresponding "mode of production" or economic system, including a certain class structure of society. The economic system, however, cannot adapt continuously. The reason is that each ruling class, once it has assumed power, erects what Marx called an "ideological superstructure", including the government, politics, religion, art, literature, philosophy and science, which has the purpose to defend the existing class structure. By the rigidity of this superstructure, the economic system is prevented from adapting smoothly to the productive forces. There is a growing tension between the two, and when the tension has reached a critical point, there is a revolution. A new class will assume power, the economic system is adapted to the productive forces in a big leap, and the game can begin anew. All history, therefore, is a history of revolutions.

Marx, in turn, was inspired to his model of history by the dialectic philosophy of Georg Wilhelm Friedrich Hegel, who thought that the history of the human mind moves in $3 / 4$ beat, namely from a thesis to its opposite, the antithesis, which are both then integrated into a synthesis, and so on, 1-2-3, 1-2-3, 1-2-3. Behind Hegel we find the Italian 18th-century sociologist Giambattista Vico, who believed that human history and political institutions had progressed in three distinct stages, and we can follow this notion back to the mythology of a golden, silver, bronze and iron age. Indeed, the question is whether the idea of a cyclical progress of history isn't essentially mythological in nature, be it in Hegel, Marx, Schumpeter or Kuhn.

\section{A Review of Revolutions in Economic Theory}

To answer this question for the limited field of economic theory I shall now review a number of episodes that were called revolutions. In each case we should like to know whether it is possible to identify a relaxation mechanism of the sort just

(Bronfenbrenner 1971, 138). 
described. Was there a growing discrepancy between theory and observation? Did the new theory make the old theory obsolete or was it merely added to it? Was there a change in "world view"? Was innovation resisted by a power structure until the growing tension caused its collapse?

\section{The Marginalist Revolution}

The first theoretical advance which is traditionally called a revolution is supposed to have taken place in 1871-74. Initiated by three "founders", namely Stanley Jevons, Carl Menger and Léon Walras, it is said to have toppled the classical orthodoxy of constant-cost value theory, represented by John Stuart Mill. After two decades of struggle, so Schumpeter tells the story, there emerged the new synthesis of neoclassical economics with the apparent "finality of a Greek temple that spreads its perfect lines against a cloudless sky" (Schumpeter, 1954, 754). On the surface, this seems to be a perfect example of a scientific revolution.

In fact, it is more mythology than history, disseminated largely by Menger's disciples in Vienna. The fundamental principles of marginalism had been developed long before 1871, namely the theory of the firm in 1838 by Antoine Augustin Cournot, the marginal productivity theory of distribution in 1850 by Johann Heinrich von Thünen, and the theory of utility maximization by Hermann Heinrich Gossen in 1854 (who saw himself as the Copernicus of the social universe). The books of the supposed founders, when they appeared, created hardly a stir. Jevons never even knew about Menger's existence. Nor was there a change in the underlying "world view". Far from discarding the traditional paradigm of the utility-maximizing "economic man", the marginalists made it the center piece of an explicit analysis. Classical theory was shown to lack generality, but it was not invalidated. Marshall soon proclaimed the synthesis which Thorsten Veblen later called "neoclassical". Even the wage-fund doctrine and the cost theory of value retained a place in the marginalist analysis for special cases. It is true that Jevons felt oppressed, both in logics and economics, by the authority of John Stuart Mill, but if there was an academic struggle, it was not against classical orthodoxy but 
against the common enemy of both classicals and marginalists, namely the historical school. ${ }^{6}$ The main struggle of the marginalists, however, was not with opposing academic schools but with the recalcitrance of their subject matter. In fact, by the end of the century the edifice of marginalist theory was still very incomplete. There was no Greek temple. Most of the economists of that generation, all too conscious of the shortcomings of their techniques and sometimes even depressed by them, were not even able to complete their planned treatises - Jevons, Menger, Walras, Marshall, and Wicksell all illustrate the point. Today the historiographers seem to agree: marginalism brought indeed an enormous advance, but there was no marginal revolution (Blaug 1972).

\section{The Monopolistic (Imperfect) Competition Revolution}

The next revolution, in conventional historiography, was that of monopolistic or imperfect competition, jointly initiated by Edward Chamberlin and Joan Robinson (and perhaps Heinrich von Stackelberg) in 1933. Chamberlin described his book as no less than a "re-orientation of the theory of value" (Chamberlin 1946), and Schumpeter said that it claimed to teach a new Weltanschauung, a new world view, "from the standpoint of which practically all economic problems appear in a new light" (Schumpeter 1954, 1151). This surely sounds like one of Kuhn's paradigm changes. Fifty years later, Blaug still accepted Chamberlin's revolutionary self-interpretation (Blaug 1985, 396). ${ }^{7}$

Looking back over the last 60 years, it is difficult to justfy this claim. Joan Robinson was much closer to the truth when she described her work as "a restatement of current ideas" which also contains some new ideas (Robinson 1950, V). It is true that Chamberlin and Robinson lifted the theory of the firm to a higher plane. Most of their

6 This was noted by Martin Bronfenbrenner (1971, 144) and Mark Blaug $(1985,300)$.

7 It is interesting to note that Blaug concedes the title of "true revolutionary" to Chamberlin, but not to Robinson $(1985,392)$. In view of the fact that Chamberlin's theoretical analysis does not go beyond Robinson's this mainly seems to show how easily even careful historians succumb to the temptation to accept thier authors' self-interpretations. 
analytical tools, however, had been available since Cournot. Today it is difficult for the historian to understand that many of those tools, even though Marshall had described Cournot as his teacher of techniques, had not found their way into mainstream economics by the time of World War I. Even the famous tangency case of monopolists whose profits are anchored at zero by free exit and entry had been described by Wilhelm Launhardt as early as 1885, and it may be argued that it is the case of Adam Smith's firm whose division of labor is limited by the size of the market. To have finally made these concepts a part of mainstream economics was certainly a valuable contribution, but it was not a breakthrough of an avant-guard but rather a successful rear-guard action. Mainstream economics was enriched, to be sure, but the theories of perfect competition and monopoly did not thereby become obsolete. In fact, the theory of perfect competition reached its high point in Arrow-Debreu equilibrium long after Chamberlin and Robinson.

\section{The Keynesian Revolution}

In some respects, the General Theory of Employment, Interest and Money by John Maynard Keynes created the prototype of a scientific revolution in economics. The book was meant as a challenge for leadership of the economics profession 8 and its revolutionary intentions were quickly recognized (Knight 1937 provides an example). Its argument was presented as a polemic attack on the "orthodoxy" of "classical" economics, which was defined to include virtually everything up to Keynes and was personified in Marshall's successor (and Keynes's colleague) Arthur Cecil Pigou. The defining characteristic of the orthodox "world view" was supposed to be the belief in Say's law, in the built-in tendency of the economy to create full employment. To this, Keynes opposed his revolutionary view, formalized in his own model, that there was no

8 As early as January 1, 1935, Keynes wrote in an often-quoted letter to George Bernard Shaw that he was engaged in writing a book "which will largely revolutionize ... the way the world thinks about economic problems". He added, strangely enough, that "the Ricardian foundations of Marxism will be knocked away" (Keynes 1973, 492-3). 
such tendency and that there may be economic equilibrium with persistent unemployment. While Keynes' own generation remained 'mostly unconvinced, many brillant economists of the younger generation became Keynesians. Keynes became the preeminent economist of his age, one of the three most famous economists of all ages (besides Smith and Marx), the "man who revolutionized capitalism".

More than half a century later the revolutionary character of Keynesianism is less clear. It was soon acknowledged even by Keynesians that, in fact, Keynes had never demonstrated the possibility of an underemployment equilibrium. Unemployment was still, in principle, a disequilibrium phenomenon, just as economists had always maintained. That Keynesian unemployment appeared as durable was simply due to the assumption of rigid money wages. By thus explaining unemployment by wage rigidity, Keynes was close to Pigou, who had done the same in 1933. Far from providing a more general theory, Keynes had in fact provided a more lucid and more articulate theory for the special short-run case of rigid money wages. This was an important contribution, particularly in those depression years, but it was more a temporary shift in emphasis than a scientific revolution.

As matter of fact, it was precisely the Keynesians (particularly the American Keynesians) who made it their program to integrate Keynesian macroeconomics with pre-Keynesian microeconomics. The result was what Samuelson called, in Hegelian terms, the "neoclassical synthesis", which essentially was an effort to derive the Keynesian propensities from microeconomic optimization. At the same time, growth theory embedded the Keynesian short-run analysis again in the classical long-run perspective. Keynes was absorbed by the classical tradition. Those on the Keynesian left wing, particularly in England, who had expected from Keynesianism a radical change of the economic system, were of course disappointed. This was the origin of the bitter controversy between Cambridge, England, and Cambridge, Masachusetts. Some will perhaps say that on this controversy the jury is still out, but it is clear that the preKeynesian tradition of economics is alive and well, enriched and invigorated by the Keynesian extensions. 
Keynes, like Smith and Marx, was a genius of persuasion. By creating a disfigured straw man of "classical" economics to knock over, he persuaded a large number of his younger contemporaries that they could take part in a scientific revolution. Today it is easy to see that the Keynesian episode brought much important progress, but it is difficult to see a revolution in the sense of Kuhn, Schumpeter or Marx.

\section{The Game Theory Revolution}

Eight years after the Keynesian revolution there was talk of yet another revolution, namely the "game theory revolution" initiated in 1944 by the Theory of Games and Economic Behavior by John von Neumann and Oskar Morgenstern. It brought two fundamental additions to the theory of economic behavior. First, it shifted the focus of theoretical research to reactive behavior, to situations in which agents are not confronted with a large anonymous market but have to take into account the reactions of other agents. Second, in view of the uncertainty of outcomes, the maximization of utility was generalized to the maximization of expected utility, which was shown to imply cardinal measurability of utility.

The immediate success of game theory exceeded its authors' expectations. A new mathematical discipline was born with important applications to statistics, operations research, political science, biology, computer science, and military decisions. Some observers also expected a revolution in economic theory. Indeed, there were many important applications to oligopoly, bilateral monopoly, coalitions, bargaining and the like. Walrasian general equilibrium with its parametric prices was generalized to Nash equilibrium. Yet the revolution did not materialize. In their authoritative introduction to the theory of games of 1957, Duncan Luce and Howard Raiffa said that initially there had been "a naive band-wagon feeling that game theory solved innumerable problems of sociologyy and economics", but they concluded that "this has not turned out to be the case" (Luce and Raiffa 1958, 10). 
This does not mean that game theory did not make an important contribution it did, and after almost half a century the contribution is still growing rapidly, as a perusal of the American Economic Review will quickly reveal. It means however, that the contribution did not take the form of a revolution but of gradual, and rather slow, evolution. After all, the first explicit model of reactive behavior had been provided by Cournot as early as 1838 , and Nash's solution concept is a direct extension of Cournot's. Coalitions had been introduced into price theory by Edgeworth in 1881, and he had created the concept that game theorists later called the "core". While the uncertainty of outcomes usually implies, in one way or another, cardinal utility, ordinal utility still dominates the field where uncertainty does not play an essential role. And most fundamentally, game theory did not bring a change in the theorist's "world view". In his early paper of 1928, von Neumann explicitly accepted the paradigm of the "economic man" and he described his theory as an effort to define rational behavior in the presence of uncertainty. Utility maximization had conquered a new field.

\section{The Monetarist Counterrevolution}

By 1962 Keynesianism seemed to be firmly in control. In the same year, Robert Clower described current developments in economic theory as a "counterrevolution" (Clower 1965) which threatened to obliterate the revolutionary achievements. These were the years when Milton Friedman reminded the profession that "money matters" for macroeconomic policy, but that the effects of monetary policy are so slow and unpredictable that it is better not to use it for short-term stabilization purposes. The experiences of the early 1960s also reminded economists of the old insight, demonstrated by John Law in 1720 and revived by Irving Fisher at the end of the 19th century, that only unexpected inflation has a stimulating effect on output, whereas expected inflation may well be associated with stagnation. For this whole body of thought, Karl Brunner in 1968 created the label of "monetarism". At first Friedman did not like this label; he thought the scope of his message went far beyond money. But the label stuck, and the new "ism" was interpreted as a counterrevolution against what was then described as Keynesian orthodoxy. 
At the level of policy applications, with respect to the "art of central banking", the two "isms" were indeed wide apart, the Keynesians advocating monetary and fiscal "fine tuning", even at the cost of some inflation, whereas the monetarists called for a steady expansion of the money supply at a non-inflationary rate. Monetarism reached its high-water mark toward the end of the 1970s, when monetary targeting was successfully used by the Federal Reserve (under Paul Volcker) to break the back of secular inflation. This was a historical contribution. At the level of theory, however, it was increasingly hard to tell the two camps apart. They used similar macroeconomic models. They agreed that, in principle, monetary policy matters. They also agreed that, in principle, fiscal policy matters. They just seemed to disagree about how much, precisely, the two mattered, relatively much or relatively little, which was hardly a fundamental difference. With respect to their political ideologies and social views, the typical Keynesian and the typical monetarist would indeed have quite different "world views", but with respect to their scientific "paradigm" they would be difficult to tell apart.

Overall, the monetarist controversy tended to confirm that the formation of "schools" is an impediment to scientific progress rather than a stimulus. Schools are important as academic power structures that try to control hiring, promotion and firing, the organization of conferences, the acceptance or rejection of papers, the allocation of research funds, and the selection of book reviewers. In economic theory, fortunately, their influence has not been very strong and durable, at least not in the present century. Our profession has become too large, too diversified, and too, seemingly, "chaotic" to be dominated by any "ism", any sort of orthodoxy, any "ideological superstructure" for very long.

\section{The Rational Expectations Revolution}

Keynesians and monetarists were united in the conviction that in the short run money has powerful real effects on the economy - this is precisely why the Keynesians wanted to use it and monetarists did not. This seemed to be denied by still another 
movement that developed over the 1970 and was soon labeled the "rational expectations revolution". 9 The concept of rational expectations was invented by John Muth as early as 1961 (Muth 1961), but it lay dormant until it was revived by Robert Lucas in the early 1970. Scientifically it was probably one of the most fruitful concepts of the postwar period. As a banner of revolution, however, it seemed oddly out of place. Muth's basic idea was that economic agents are too intelligent to form their expectations by simply extrapolating past trends. Instead, he argued, they form in their minds the best possible economic models and use these to produce their forecasts. This means that expectations formation is brought within the purview of optimizing behavior. While optimization was applied in the 19th century to consumption, production, demand and supply, it was now extended to expectations. The paradigm of economic rationality remained the same, but its domain was further enlarged. This was hardly a revolutionary program, though a promising one.

The denial of any real effects of monetary policy, which seemed to be so revolutionary, soon turned out to be untenable. In fact, Lucas's program was precisely to show why money may have powerful real effects on output and employment, and the "policy ineffectiveness proposition" related only to rules of monetary policy rules, to "programmed" policies, and not to discretionary actions in ever-changing situations. As a consequence, the effect on policy-making was small, and the most tangible effect was on econometric methods.

The rational expectations approach involved one unconventional step, though. Muth and his successors postulated that the best model for everybody is simply the one that the respective econometrician happens to have in mind. In view of the imperfect state of econometrics this looks provocatively dogmatic and almost arrogant. In a more modest approach, each individual would be assumed to form his or her own best model of the world, optimized in light of his or her specific experience. As a consequence, different people would be allowed to have different expectations, all of which would be equally rational, though many of them would turn out to be false. With this additional

9 This label was clearly invited by Lucas and Sargent (1981). 
step, rational expectations would be back in the mainstream of 19 th century subjectivism, the distinction between rational and irrational expectations would tend to disappear.

Concluding this brief review of alleged revolutions in economic theory, it appears that the Keynesian revolution was the only one that comes at all close to fitting the dialectic model of Kuhn, Schumpeter, or Marx. And even in the Keynesian case, the revolutionary appearance owes more to Keynes's deliberate efforts to present himself as a revolutionay against classical orthodoxy than to the judgment of impartial observers. If, therefore, economic theory does not typically advance in the $3 / 4$ beat of Hegelian dialectics, how does it, in fact, advance?

\section{The Progress of Economics: Some Salient Features}

Some salient features of the progress of economics, as they emerge from its past history, will now be outlined.

1. The Immutability of the Economic Paradigm

First we note that economic theory is indeed based, to use Kuhnian terms, on a fundamental paradigm or "world view", 10 and that this has remained unchanged over the centuries. 11 This paradigm is the "economic man", who makes rational decisions in the sense that he (or she) tries to make the best of any given situation. ${ }^{12}$ This

10 Which was doubted by Kuhn for the social sciences $(1970,15)$.

11 The argument of this section was admirably presented by Donald F. Gordon more than 25 years ago (Gordon 1965).

12 A. W. Coats $(1969,292)$ identifies the enduring paradigm of economics as "the theory of economic equilibrium via the market mechanism". I believe this is too narrow a definition. Extensions of rational behavior to disequilibrium situations and to non-market allocations are not typically regarded as scientific "catastrophs" but as welcome, and perhaps natural, generalizations of fundamental theory. 
paradigm first attracted attention in the work of Adam Smith, who subscribed to the commonsense view that men, by and large, are motivated by their own interests, which may include the conclusion of contracts, the formation of coalitions and the creation of institutions for the enforcement of contracts and coalitions. The paradigm is actually much older, and when the scholastic doctors of late--medieval and early modern universities tried to clarify the meaning of a "just" price as arising from the "nature of things", it is just this sort of rational behavior they had in mind. And indeed it would be surprising if Aristotle had not visualized his contemporaries in similar commonsensical terms. About sixty years after the Wealth of Nations William Forster Lloyd gave this paradigmatic economic man the name of Robinson Crusoe, who was then joined by Good Man Friday once the discussion turned to exchange.

Everybody always knew, of course, that man is not always rational, but of ten confused, inconsistent, traditional, emotional, self-sacrificing or even self-destructive. Economists were content, however, to leave these aspects, important as they might be, to the philosophers, theologians, dramatists, novelists, politicians, historians, psychologists and sociologists. For this they were severely criticized, from Adam Smith's days to the present time, most severely by the Romantics and historicists of the 19 th century. This chorus of critical voices is another of the great constants in the history of economics. The final demise of homo oeconomicus was announced every few years for the last two centuries.

None of theșe "rebellions", however, achieved a successful revolution. ${ }^{13}$ Undaunted, economic theorists continued to find the optimizing paradigm fruitful. In fact, the whole history of economic theory during the past centuries can be interpreted as a more and more detailed and general elaboration of the concept of rational behavior and its implications for the economy. Adam Smith's metaphor of the invisible hand was still rather vague. Cournot applied the concept of rational behavior to the firm. Thünen provided an explicit theory of rational behavior for a producer. Gossen did the same thing for the consumer. Walras investigated the implications of individual rationality for

13 Gordon $(1965,124)$ used almost the same words. 
the efficiency of the economy as a whole, a program that three quarters of a century later led to Arrow-Debreu equilibrium. Linear programming extended the analysis to corner solutions and made results computable. Game theory extended the concept of rationality to reactive, small-group situations with uncertain outcomes. Rational expectations broadened the rationality concept to include the formation of expectations. Despite its questionable realism, the paradigm of economic theory seems to be indestructible and inexhaustible.

How can this be so? Why did economists never feel compelled to discard obsolete paradigms in favor of new ones, as Kuhn describes it for physics? By and large this is, as Menger maintained against Schmoller, because pure economic theory is largely restricted to those aspects of human behavior which remain roughly the same for centuries, if not millenia. As far as substantive knowledge of human motivations is concerned, general equilibrium theory, game theory, linear programming and rational expectations might just as well have been invented 500 years ago. The state of technology, the level of economic progress, the state of the natural sciences, and political and economic institutions (except the separation of firms from households) were largely immaterial. What mattered was the state of mathematics. We find, therefore, that all schools and isms (including the marxists) shared the same immutable paradigm, no matter how much they differed in their applications, ideologies and policy prescriptions.

\section{The Unimportance of Falsification}

According to Karl Popper, science consists of empirical hypotheses that have survived many serious efforts to prove them false. According to Kuhn, growing discrepancies between theory and observation would gradually lead to a crisis, and finally to a change in paradigm, a scientific revolution. This idea left its imprint on economic literature. For a time, even mathematical economists felt an obligation to point out that their results could be tested empirically, at least in principle; there was 
an impressive rhethoric about falsifiable hypotheses; and econometrics seemed to promise to make economics an empirical science like "any other".

As it turned out, econometrics, though it accomplished a lot, did not live up to this promise. To the present day, economics contains few "confirmed", generally accepted empirical propositions. Hardly any "great constants" have been discovered, however hard people like Nicholas Kaldor might have tried. Few economic theories have ever been discarded because they did not fit the empirical facts.

As a matter of fact, while empirical observation plays an enormous role in economics as history, doctrine and art, it plays an insignificant role in economic theory. A look at first-rate journals is enough to demonstrate that economic theory is still a collection of pieces of pure logic, largely expressed in mathematical symbols; it is still the "pure logic of choice". In the course of the last 150 years this feature became actually more and more pronounced, and today the leading younger theorists seem to be applied (if not pure) mathematicians.

This is consistent with the observation that few pieces of economic theory are ever completely discarded. The balance of payments concept, invented by the mercantilists as the first system of national accounts, is still in use. David Hume's feeedback-control specie-flow mechanism is still with us. The 18th-century Tableau Économique was resurrected in Leontief's input-output analysis. Ricardo's comparative cost theory lives on in linear programming. The classical cost theories of value were integrated into the marginalist utility theories. Even the wage fund theory was revived by Böhm-Bawerk and lives on in the "Austrian" theory of capital. What Keynes called the "classical" system survived his attack without serious injury, just as the Keynesian contribution survived the monetarist counterrevolution. Like mathematics, economic theory seems to grow without any of its parts really seeming to die. From the natural sciences we know those pronouncements that the half-life of modern scientific truth is, say, 15 years. In economic theory it is easy to see that fads and fashions in dissertation topics change in less than 15 years, but truth, once established, is almost immortal, though probably very incomplete and mixed with error. 


\section{The Driving Forces}

If you grant me that economic theory is not driven forward by discrepancies between existing theory and observation, what are the forces that drive economic theory forward? It is customary, particularly in the Marxian tradition, to assign the primary role to external impulses, such as political events, social problems, and economic developments. It is true that these have been of great importance as psychological motives for individual economists. Many of the brightest stars were drawn into economics by social concerns, by the ambition to contribute to the solution of urgent problems. If we survey the history of economic theory as a whole, however, the influence of external events is conspicuous rather by its weakness than by its strength. ${ }^{14}$ It is true that recurrent crises called for a theory of business cycles, and it was depression which produced the Keynesian model, but the Tableau Économique, the theory of comparative cost, marginal utility theory, the marginal productivity theory of distribution, the theory of games, the theory of rational expectations could just as well have been developed under very different conditions. It is particularly remarkable how pluralistic economic theory is with respect to political ideologies, leftwing radicals like Wicksell, bourgeois Christians like John Bates Clark, right-wing conservatives like Pareto, and a communist agitator like Eugene Slutsky all joining forces in forging the same "neoclassical" tools.

The main driving force of scientific progress did not come from the outside, but from inside of economic theory. Economic science was driven forward mostly by the logical flaws in existing theory. Some of these flaws consist in a lack of precision. Thus Adam Smith was certainly imprecise when he described a monopoly price as the highest that can be got, and his imprecision was an invitation to Cournot to do better. Keynes was similarly imprecise in explaining his theory, and this led to Hicks's IS-LM model. Another source of logical flaws is inconsistency. Thus the inconsistency of Hume's price-specie-flow mechanism with the law of one price led to a two-century long debate about the role of price differentials in the transfer process. The possibility of negative

${ }^{14}$ This has been argued forcefully by George Stigler $(1965,16-30)$. 
prices in the Walrasian equilibrium led to modern existence proofs. The inconsistency of pure competition with increasing returns to scale in Marshall's theory led to imperfect and monopolistic competition. The inconsistency of expectations derived by extrapolating the variables in a model with those derived from the model itself led to rational expectations. A third, and most important, type of logical flaw is lack of generality. To construct a general price theory that would include the polar cases of constant costs and of fixed supply as special cases was an important item on the marginalist agenda. Harrod generalized Keynes's theory by including the capacity effect of investment. Cournot, Edgeworth, and von Neumann generalized price theory by extending it to reactive behavior and coalitions. Rational expectations generalized marginalist theory by extending optimization to expectations formation.

Overall, there seems to be much truth in the notion that the progress of economic theory is mainly driven by the detection and correction of logical flaws. As a consequence, the same commonplace insights, available centuries ago, are expressed in models that are progressively more precise, consistent, general, and intelligible. This is particulariy true for the core of economic theory. Beyond the core, however, much has been added to economic theory that cannot be explained by the elimination of logical flaws.

The transformation of external impulses and logical flaws into scientific achievement requires creative minds, combining high analytical ability with intuitive vision for fruitful problems. Vision without analysis is cheap; analysis without vision is tedious. It was usually the combination of the two that led to classic contributions.

To what extent has the progress of economic theory been shaped by creative minds? A partial answer can be obtained from the study of multiple discoveries. ${ }^{15}$ The classical theory of rent was discovered independently by Anderson, West and Malthus. Gossen's second law was rediscovered by Jevons and Walras (but not by

15 This field of study has been opened by Robert Merton. Multiple discoveries in economics are analyzed in Niehans (1992). 
Menger). The golden rule of growth was independently discovered by about seven persons. These examples can be multiplied almost at will. In fact, it is difficult to find important discoveries which were not duplicated or nearly duplicated. The theory of games and rational expectations are possible examples of singular discoveries. This seems to suggest that the direction of theoretical progress in economics does not depend very much on individual minds, however brilliant and creative. The next step which theory takes seems to be roughly determined by the steps that have preceded it. There is something else, however, for which creative and brilliant minds seem to be decisive,

that is the speed at which theory advances along its largely predetermined path. If creative minds are lacking, the river of theoretical progress stagnates; it takes decades before the next step is taken. The re-invention of marginal revenue ninety years after Cournot is a case in point. If creative minds are abundant, logical flaws are eliminated in rapid succession. Often, in fact, progress has been dispairingly slow. Cournot took a century to be absorbed by mainstream economics, Thünen and Gossen took a quarter century, Von Neumann's early game theory paper remained unnoticed for 16 years, Muth's rational expectations hypothesis for 10 years. Creative minds are still scarce.

\section{The Relevance Test}

The description of scientific progress outlined in the last few minutes gives rise to an obvious, but important, question: If economic theory consists of pieces of logics and mathematics, what on earth does it have to do with economic reality? Is it just a game intelligent people play? The general answer is that every piece of economic analysis, however abstract, eventually has to pass a relevance test. Let me try to explain.

Economists would love to discover empirical laws of the type of those in physics or chemistry. They tried hard to find them and many are still trying, but so far the result has been largely negative. The probable reason is that the process of human history is a unique chain of events with very few repetitive elements. It looks, metaphorically, like a chaotic process, which may well be strictly determinate, but in 
which everything looks as if it were random. The consequence is that the economist, faced with a much more complicated universe than the physicist, has to build a new model for every question he wants to answer. Economics is a science of unique events. In principle, models for empirical purposes are throw-away, never to be used twice. But building a model from scratch is a difficult and time-consuming task. It is very helpful, therefore, if the economist has at his disposal an inventory of prefabricated pieces of analysis which he can use as component parts of his own particular model. This inventory is what we call mainstream economic theory. Mainstream theory is not a picture of economic reality. Strictly speaking, it says nothing about economic reality, but it is very useful to have an inventory of analytical components, from which, in each particular case, a useful picture of economic reality can be built.

Now the number of possible pieces of analysis is infinite, and an infinite inventory would be unmanageable. How does economic science select those pieces of analysis that are worthy of becoming part of mainstream economics, how does it identify those that should be eliminated? The test is whether a piece of analysis promises to be helpful in solving practical problems. Pieces that prove helpful are retained in mainstream economics; pieces that are never used are eliminated. Economic theories are hardly ever refuted, they are just forgotten. To paraphrase the song about old soldiers: "Old theories never die, they only fade away". This is the vital link that ultimately connects economic theory to economic reality.

\section{An Evolutionary View of Economic Theory}

I began this lecture by outlining a revolutionary conception of the history of economic theory. This model was then compared with the historical facts. What finally merged was a very different view, namely an evolutionary conception of scientific progress.

Over the centuries, the history of economic theory has been one of monotonic, cumulative progress. What scholastic, mercantilist and classical economists thought 
about economic problems still makes sense in modern terms, but modern mainstream theory is vastly richer, clearer, more consistent, more general, and less mixed with fallacies. From the scholastic "just price" to game theory and rational expectations there is an unbroken pedigree. This progress has always been accompanied by vociferous dissent, which has often made it difficult for the contemporaries to distinguish progress from error. Many ambitious individuals tried to gain glory by proclaiming revolutions, and one of them, Keynes, actually did, but all of these rebellions were rapidly absorbed by the main stream. There were no scientific revolutions in the sense of Kuhn or Marx.

The absence of real revolutions in economic theory is largely due, I think, to the multiplicity of competing "schools" and "isms" and thus to the relative weakness of each one of them. There are exceptions. The historical school dominated German universities around 1880 to such an extent that for almost half a century German economists made no contributions to mainstream economics. By and large, however, the market place for ideas remained open, and it is more open today than it was ever before. While many blamed resistance against their ideas to "orthodoxy", 16 most everybody can in fact get a hearing. The personal success of Keynes actually put a premium of iconoclasm. As a consequence, there was, in Marxian terms, no rigid ideological superstructure to produce a tension-relaxation mechanism.

The flow of mainstream economics is driven forward partly by external (political, ideological, social, economic) influences, partly by the growing mathematical competence of economists, partly also by the increasing resources devoted to economics. For the most part, however, it is driven by the recognition of logical flaws in existing theory. From the large number of multiple discoveries one is tempted to conclude that there must be a strong deterministic element in this process. At each moment, the next step tends to concern the flaws that are easiest to correct. The best economic theorists do not attack the most urgent problems, but those that have finally become solvable.

16 A complaint by a non-Keyesian against what he regarded as Keynesian orthodoxy is quoted by Coats $(1969,294)$. 
But, as has been said a minute ago, the number of possible pieces of analysis is infinite, and an extremely large number of them is presented to the public every year. How is it decided which of these pieces will eventually become part of mainstream economics? This is the same sort of question as in biology the selection of the mutations that finally become new species. The answer is similar, too [Remember that it was the economist Malthus who inspired both Darwin and Wallace to their theories of the origin of species]. There are, fortunately, no authorities to watch over the unity of doctrine and the purity of the faith. The selection is made in the market place for ideas, in the seemingly chaotic babble of economic controversies. This intellectual market place selects those analytical pieces which promise to be relevant, sooner or later, in the practical solution of economic problems, while other pieces are discarded. This selection process, just like biological selection, is an inherently wasteful process. Of all theoretical papers published each year, only a small fraction will later turn out to have become part of mainstream economics, the judgment of the market is fallible, and fame is not always accorded in proportion to achievement.

This evolutionary view of economic theory is not new, to be sure. In fact, it has been the view of many economists, great and small. It was surely the view of Adam Smith, of Ricardo who took his departure from Smith, of Mill who built on Ricardo, of Marshall who based himself on Mill, of Menger, Wicksell, Fisher, Samuelson, or Arrow. In a sense, it is simply the view of the true scholar who tries to add a further story to the building erected by his predecessors. In recent jargon it has become customary to call such scholars "neoclassical". I always found it hard to associate with this word any specific doctrines. Prevalent notions about its substantive meaning seem to change every decade; what today is seen to be the opposite of neoclassical may be regarded as neoclassical tomorrow. I thus ended up by identifying neoclassical economics simply with mainstream economics, the economics that at any given time is counted as part of the working inventory of theoretical tools, its content determined by the evolutionary selection in the chaotic and wide-open market place of ideas. 


\section{Bibliography}

Blaug, Mark. 1972. Was there a marginal revolution? History of Political Economy 4 (2): $269-80$.

1985. Economic Theory in Retrospect. 4th ed. Cambridge (Cambridge University Press).

Bronfenbrenner, Martin. 1971. The "structure of revolutions" in economic thought. History of Political Economy 3 (1): 136-51.

Chamberlin, Edward H. 1946. The Theory of Monopolistic Competition: A Reorientation of the Theory of Value. 5th ed. Cambridge, Mass. (Harvard University Press).

Clower, Robert. 1965. The Keynesian counterrevolution: a theoretical appraisal. In F. Hahn and F. P. R. Brechling (eds.). The Theory of Interest Rates. New York (St. Martin's Press): 103-25.

Coats, A. W. 1969. Is there a "structure of scientific revolutions" in economics? Kyklos 12 (2): 289-296.

Gordon, Donald F. 1965. The role of the history of economic thought in the understanding of modern economic theory. American Economic Review 55 (2): 119-27.

Hutchison, Terence W. 1978. On Revolutions and Progress in Economic Knowledge. Cambridge (Cambridge University Press).

Keynes, John M. 1936. The General Theory of Employment, Interest and Money. London (Macmillan). 
1973. The Collected Writings. Vol. XIII. Ed. D. Moggridge. London (Macmillan).

Knight, Frank H. 1937. Unemployment and Mr. Keynes's revolution in economic theory. Canadian Journal of Economics and Political Science 3(1): 100-23.

Kuenne, Robert E. (ed.). 1967. Monopolistic Competition Theory: Studies in Impact: Essays in Honor of Edward H. Chamberlin. New York (Wiley).

Kuhn, Thomas S. 1970. The Structure of Scientific Revolutions. 2nd ed. Chicago (University of Chicago Press).

Lucas, Robert E., and Thomas J. Sargent. 1981. After keynesian macroeconomics (1979). In R. E. Lucas and T. J. Sargent (eds.). Rational Expectations and Econometric Practice. Minneapolis (University of Minnesota Press).

Luce, Duncan R., and Howard Raiffa. 1958. Games and Decisions: Introduction and Critical Survey. New York (Wiley).

Merton, Robert K. 1961. Singletons and multiples in scientific discovery: a chapter in the sociology of science. Proceedings of the American Philosophical Society 105(5): 470-86.

Muth, John F. 1961. Rational expectations and the theory of price movements. Econometrica 29(3): 315-35.

Neumann, John von, and Oskar Morgenstern. 1947. Theory of Games and Economic Behavior. 2nd ed. Princeton, N.J. (Princeton University Press).

Niehans, Jürg. 1981. Economics: history, doctrine, science, art. Kyklos 34(2): 165-77. 1990. A History of Economic Theory: Classic Contributions, 1720-1980. Baltimore (Johns Hopkins University Press). 
1992. Multiple Entdeckungen in der Wirtschaftstheorie. Sitzungsberichte der Bayerischen Akademie der Wissenschaften, Munich.

Robinson, Joan. 1950. The Economics of Imperfect Competition. Reprint. London (Macmillan).

Schumpeter, Joseph A. 1954. History of Economic Analysis. Ed. E. Boody Schumpeter. New York (Oxford University Press).

Stigler, George J. 1965. Essays in the History of Economics. Chicago (University of Chicago Press). 
Revolution and Evolution in Economic Theory

\section{A Comment}

E. Jürg Weber ${ }^{1}$

I would like to thank Professor Jürg Niehans for his important and stimulating Bateman lecture. Every now and then, we are touched by an original piece of analysis or idea that will stay with us. This is what has happened tonight. Jürg Niehans has provided us with a lucid analysis of the evolution of economic theory that will have a lasting effect on all of us.

According to Jürg Niehans, three features characterize the evolution of economic theory:

(1) Multiple discoveries by independent researchers are common. For example, marginalism was discovered and rediscovered by Cournot, Thünen, Gossen, Jevons, Menger and Walras over a period of 40 years.

(2) Few economic theories are ever refuted by empirical research. The quantity theory of money, which was a piece of commonplace economics during the Middle Ages, is still used in the analysis of the behavior of the price level in a modern economy with fiat money.

(3) People with opposing ideologies are contributing to economic theory. Slutsky had a successful academic career under Stalin. Yet his analytical contribution to economics was nothing less than the substitution and income effect in the theory of consumer behavior.

1. Department of Economics, University of Western Australia. 
The first observation that economic theorems tend to be simultaneously discovered by several people shows that, at each point in time, the existing body of knowledge determines the next step that economics will take. Consider for example the recent emergence of real business cycle models in macroeconomics. In those models technological shocks produce business cycles through intertemporal optimization by consumers. Thus, real business cycle models generalize older theories that stress intertemporal optimization, including the permanent income hypothesis and rational expectation models.

The second observation that few economic theories are refuted by empirical research suggests that economics consists of an edifice of logical propositions. In his book on "A History of Economic Theory", Jürg Niehans argues that economic theory started with commonplace notions. ${ }^{2}$ Progress has then been driven by a search for precision and the removal of inconsistencies. In the 1980s, real business cycle models became feasible because economists had gained the mathematical skills to handle them. These models will not be refuted by empirical research because they are extensions of earlier, less consistent models. Naturally, this does not mean that economists may never lose interest into those models. Real business cycle models will fade away (but not be refuted) if monetary factors continue to account for recessions. It is now generally accepted that the current recession in Australia was caused by the monetary contraction that was engineered by the Reserve Bank in the late 1980s.

Economic theory is the "pure logic of choice". This also explains why the recent rapid expansion in the availability of computing time has not led to a corresponding explosion in economic knowledge. Today, personal computers are virtually a free good at universities. Yet it seems that our knowledge of the short run 1980, Baltimore: Johns Hopkins University Press, 1990. 
response of real variables to monetary shocks is not superior to that of classical monetary economists like, for example, Thornton. Indeed, it was the empirical knowledge of those economists that, two centuries ago, has started a process of economic inquiry and model building that is still continuing.

The third observation that economists are contributing to economic theory irrespective of personal ideologies confirms the universal nature of economics.

Jürg Niehans proposes an evolutionary model of progress in economics, as opposed to a revolutionary model. He persuasively argues that economic theory has evolved as a monotonic, cumulative process in which existing theories are continually improved upon. Kuhnian revolutions and the perennial animosities between schools of thought play no role in his analysis of scientific progress. In this way, he succeeds in exposing the popular notion of the 'dismal science' as empty talk. We are all indebted to Jürg Niehans for his profound Bateman lecture. 